\title{
Ammonium sulphate on maize crops under no tillage
}

\author{
Maria Anita Gonçalves da Silva (1*); Anny Rosi Mannigel ('); Antonio Saraiva Muniz ('); \\ Simone Maria Altoé Porto (1); Marlene Estevão Marchetti ( $\left.{ }^{2}\right)$; Antonio Nolla ( ${ }^{3}$ ); \\ Rosemary Marques de Almeida Bertani $\left({ }^{4}\right)$
}

(') Universidade Estadual de Maringá (UEM), Departamento de Agronomia, 87020-900 Maringá (PR), Brasil.

(2) Universidade Federal da Grande Dourados, Departamento de Agronomia, 79825-070 Dourados (MT), Brasil.

(3) UEM, Departamento de Agronomia, 87506-370 Umuarama (PR), Brasil.

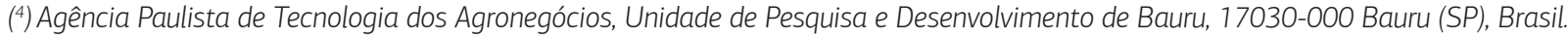

(*) Corresponding author: magsilva@uem.br

Received: Oct. 12, 2010; Accepted: Oct. 13, 2011

\begin{abstract}
The objectives of this work were to evaluate the management of $\mathrm{N}$ and $\mathrm{S}$ (as ammonium sulphate) fertilization under notillage system on the components of maize productivity and on $\mathrm{N}$ and $\mathrm{S}$ accumulation in the crop, as well as to evaluate the minimum value of the Nitrogen Sufficiency Index (NSI 0.95) as an indicator for side dressing requirements. The experiment had a completely randomized block design with six treatments and four replications carried out in Red Latosol dystrophic soil (Hapludox), in Campo Mourão, Paraná State, where the following treatments in summer growth maize were applied: T1- $120 \mathrm{~kg} \mathrm{ha}^{-1} \mathrm{~N}$ in seeding; T2- $120 \mathrm{~kg} \mathrm{ha}^{-1} \mathrm{~N}$ in side dressing; T3- $40 \mathrm{~kg} \mathrm{ha}^{-1} \mathrm{~N}$ in seeding and $80 \mathrm{~kg}$ ha-1 $\mathrm{N}$ in side dressing; T4- $30 \mathrm{~kg} \mathrm{ha}^{-1} \mathrm{~N}$ in seeding and $90 \mathrm{~kg} \mathrm{ha}^{-1} \mathrm{~N}$ in side dressing, monitored by a chlorophyll meter using the Nitrogen Sufficiency Index (NSI); T5- $120 \mathrm{~kg} \mathrm{ha}^{-1} \mathrm{~N}$ anticipated in wheat seeding; T6- without nitrogen fertilization. NSI was determined by the relationship between the leaf chlorophyll index (ICF) average of T4 plants and that one in the plot fertilized with $120 \mathrm{~kg} \mathrm{ha}^{-1} \mathrm{~N}$ at the maize seed sowing (T1). During two years, ammonium sulphate was applied to the maize crop after wheat under no tillage system. In the first year, with adequate rainfall, the maize yield was similar to the one in which the complete ammonium sulphate dose application was done in maize seeding and side dressing. The anticipated fertilization to wheat seed sowing resulted in maize yield without difference from the parceled form. In the second year, with irregular rainfall, all treatments with $\mathrm{N}$ were similar and they increased maize yield compared to that without $\mathrm{N}$ fertilization. NSI of 0.95 was not efficient to evaluate maize $\mathrm{N}$ requirements in side dressing, and resulted in lower maize yield. $\mathrm{N}$ was accumulated mainly in the grains unlike $\mathrm{S}$ that accumulated in the plant shoots; both were highly correlated to maize productivity. Key words: Zea mays, Triticum aestivum, fertilizer management, nitrogen, sulfur.
\end{abstract}

\section{Resposta à aplicação do sulfato de amônio na cultura do milho cultivado sob plantio direto}

\section{Resumo}

Os objetivos do trabalho foram avaliar o manejo de adubação com N e S (como sulfato de amônio) nos componentes de produção do milho e no N e S acumulados pela cultura, assim como avaliar o valor mínimo de Índice de Suficiência em Nitrogênio (ISN=0,95), como um indicativo da necessidade da adubação em cobertura, em plantio direto. O delineamento experimental foi blocos casualizados com seis tratamentos e quatro repetições em Latossolo Vermelho distrófico (Hapludox), em Campo Mourão (PR), utilizando os tratamentos no milho: T1 - N $120 \mathrm{~kg} \mathrm{ha}^{-1}$ na semeadura; T2- $120 \mathrm{~kg} \mathrm{ha}^{-1}$ de N em cobertura; T3- 40 $\mathrm{kg} \mathrm{ha}^{-1}$ de $\mathrm{N}$ na semeadura $80 \mathrm{~kg} \mathrm{ha}^{-1}$ de N em cobertura; T4- $30 \mathrm{~kg} \mathrm{ha}^{-1}$ de N na semeadura e $90 \mathrm{~kg}$ ha-1 $\mathrm{N}$ em cobertura, cuja necessidade foi monitorada pelo clorofilômetro, em função do Índice de Suficiência em Clorofila (ISC); T5- 120 kg N ha-1 antecipado na semeadura do trigo; T6- controle, sem aplicação de N. A necessidade da adubação nitrogenada em cobertura, no tratamento monitorado, foi avaliada pelo Índice de Suficiência em Nitrogênio (ISN), sendo determinado pela relação entre a leitura média do Índice Relativo de Clorofila Foliar (IRC) nas folhas da parcela estudada e a média da leitura do IRC na parcela de referência, a qual recebeu dose total de $\mathrm{N}$ e S na semeadura do milho. No primeiro ano, com chuvas mais regulares, o milho produziu melhor nos tratamentos onde o fertilizante foi aplicado em dose completa na semeadura ou em cobertura. A aplicação da dose completa do sulfato de amônio, antecipado na semeadura do trigo, proporcionou produtividade do milho sem diferença da adubação parcelada. Já no segundo ano, com chuvas irregulares e menor eficiência do fertilizante, não houve diferença entre as formas de manejo do sulfato de amônio na produtividade do milho na semeadura do trigo. O ISN de 0,95 não foi eficiente para avaliar o $\mathrm{N}$ requerido pelo milho na época da cobertura e a omissão do fertilizante resultou em menor produtividade do milho. O N acumulou-se mais nos grãos, enquanto o S acumulou-se mais na palha; porém ambos foram altamente correlacionados à produtividade do milho.

Palavras-chave: Zea mays, Triticum aestivum, manejo da adubação, nitrogênio, enxofre. 


\section{INTRODUCTION}

In maize, the management of $\mathrm{N}$ fertilization still requires further investigation because this nutrient has an inherent behavior in no-tillage cultivated soils. Conventionally, one third of the $\mathrm{N}$ dose is applied into the plots at seed sowing and the remaining two thirds are side dressed between the $\mathrm{V}_{4}$ and $\mathrm{V}_{8}$ stages ( 30 and 40 days), when the plants require high $\mathrm{N}$ levels (BüLL, 1993).

The application of the entire dose in side dressing has been more beneficial to maize crops than the fertilization at seed sowing. However, DA Ros et al. (2003) and DuETE et al. (2008) found out that parceled N fertilization at seed sowing and in side dressing increased the availability of $\mathrm{N}$ at the higher demand stages, and, consequently, the crop productivity. Silva et al. (2005) reported high productivities when $50 \%$ of $\mathrm{N}$ dose was applied onto the soil at seed sowing and the remaining dosage at fourth to sixth leaf stages or eighth to tenth leaf stage of plant development, or when the $\mathrm{N}$ was entirely applied on plants at the fourth to sixth leaf stages.

Furthermore, seed sowing of maize after leguminousplant cropping has better responded after grasses due to the continuous availability of $\mathrm{N}$ at the initial stages of the development (SiLVA et al., 2006; 2008). According to these authors, the $\mathrm{N}$ mineralization and immobilization is affected by the quality of organic wastes and their use by the next crops in rotational systems. Thus, the quantity of $\mathrm{N}$ in pearl millet is lower than in crotalaria which allows higher $\mathrm{N}$ contents and dry mass production. However, many reports have showed similar or even better responses with the grass-maize sequence (CERETTA et al., 2002; Silva et al., 2006; 2009a). Thus, SANGor et al. (2007) and SiLva et al. (2009b) verified higher productivity of maize after oats when $\mathrm{N}$ was parceled into dosages for side dressing application.

Immobilization and volatilization are the great causes of $\mathrm{N}$ losses (Lara Cabezas et al., 2000; 2007) and there have been significant differences in $\mathrm{N}$ fertilization response. Therefore, one maize cropping management strategy could be the anticipation of fertilizer application from the initial maize growth stage to winter wheat seed sowing to compensate the negative effects of $\mathrm{N}$ immobilization by the microbiological biomass (CERETTA et al., 2002).

The objectives of this study were to evaluate: a) the effects of the $\mathrm{N}$ and $\mathrm{S}$ fertilization management under no-tillage on maize productivity components; b) the Nitrogen Sufficiency Index $(\mathrm{NSI}<0.95)$ to determine $\mathrm{N}$ side dressing requirements; and c) the relationships and efficiency of accumulated $\mathrm{N}$ and $\mathrm{S}$ use and the maize productivity.

\section{MATERIAL AND METHODS}

The experiment was conducted in Campo Mourão, Paraná, Brazil, on a Hapludox (Red Latosol dystrophic soil, EMBRAPA,

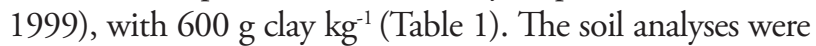
carried out according to EMBRAPA (1997). For some years, all this area has been cultivated under no-tillage with lopsided oats, wheat and lupine in the winter, and soybean and maize in the summer. In April 2003 and 2004, wheat seeds of the cultivar CD 104 were sowed and the soil fertilized with 08$30-20$ at $300 \mathrm{~kg} \mathrm{ha}^{-1}$. The wheat plots consisted of $304.0-\mathrm{m}$ long rows spaced $0.17 \mathrm{~m}$ apart, with 40 to 50 plants per meter (400.000 plants ha ${ }^{-1}$ ). In October 2003, maize hybrid seeds Pioneer 30P70 were sowed and the soil was fertilized with $300 \mathrm{~kg} \mathrm{ha}^{-1} \mathrm{P}$ and K (00-20-10). In November 2003, side dressing fertilization with ammonium sulphate was applied at the $34^{\text {th }}$ day. In November 2004, maize hybrid seeds Syngenta were then sowed. In December 2004, side dressing fertilization with ammonium sulphate was applied to the maize plants at the $32^{\text {nd }}$ day. The $40 \mathrm{~m}^{2}$ plot area $(4 \times 10 \mathrm{~m})$ had five maize lines, $0.80 \mathrm{~m}$ apart from each other $(40.000$ to 50.000 plants ha ${ }^{-1}$. The two central rows with 20 plants were used to evaluate crop productivity. The useful evaluation area of the production components, as ear mass without straw (grains + corncob), the ear length, and the number of ears per hectare, was evaluated in the four $32-\mathrm{m}^{2}$ central rows. The grains contained $13 \%$ of humidity.

The experimental had a completely randomized block design with six treatments and four replications. The results were submitted to variance analysis and evaluated by media test ( $\mathrm{F}$ test) at $5 \%$ probability. The correlation coefficient magnitude was determined between yield and absorbed nutrients for maize, using correlation test among the data. The analyses were carried out using Sisvar (FERREIRA, 2000).

The maize plots received a complete dose of $120 \mathrm{~kg}$ $\mathrm{ha}^{-1} \mathrm{~N}$ and $144 \mathrm{~kg} \mathrm{ha}^{-1} \mathrm{~S}$ which was applied as ammonium sulphate at seed sowing, in side dressing or both. The maize was fertilized with ammonium sulphate because $\mathrm{N}$ and $S$ contents were applied together.

Table 1. Soil chemical analysis before ammonium sulphate fertilization of Hapludox (Red Latosol dystrophic)

\begin{tabular}{|c|c|c|c|c|c|c|c|}
\hline Depths & $\mathrm{pH}$ & $\mathrm{pH}$ & $\mathrm{Al}^{3+}$ & $\mathrm{H}^{+}+\mathrm{Al}^{3+}$ & $\mathrm{Ca}^{2+}+\mathrm{Mg}^{2+}$ & $\mathrm{Ca}^{2+}$ & $\mathbf{K}^{+}$ \\
\hline $\mathrm{cm}$ & $\mathrm{CaCl}_{2}$ & $\mathrm{H}_{2} \mathrm{O}$ & & & $\mathrm{cmol}_{\mathrm{c}} \mathrm{dm}^{-3}$ & & \\
\hline $0-10$ & 5.1 & 5.7 & 0.0 & 4.3 & 6.0 & 4.4 & 0.3 \\
\hline $10-20$ & 4.9 & 5.5 & 0.1 & 4.6 & 5.7 & 4.1 & 0.3 \\
\hline Depths & v & C & $\mathbf{P}$ & $\mathrm{Fe}^{2+}$ & $\mathrm{Zn}^{2+}$ & $\mathrm{Cu}^{2+}$ & $\mathrm{Mn}^{2+}$ \\
\hline $\mathrm{cm}$ & $\%$ & $\mathrm{~g} \mathrm{dm}^{-3}$ & & & $\mathrm{mg} \mathrm{dm}^{-3}$ & & \\
\hline $0-10$ & 59.8 & 2. & 18 & 66.0 & 22.6 & 8.4 & 53.7 \\
\hline $10-20$ & 56.3 & 20.5 & 11 & 79.4 & 16.3 & 9.3 & 53.5 \\
\hline
\end{tabular}


The $\mathrm{N}$ treatments for maize were T1: $0-120-0$; T2: 0-0-120; T3: 0-40-80; T4: 0-30-90; T5: $120-0-0$ and T6: 0-0-0 (control). The $S$ treatments were: T1: 0-144-0; T2: 0-0-144; T3: 0-48-96; T4: 0-36-108; T5: 144-0-0 and T6: $0-0-0$ (control). The first numeric code is the early fertilizer application at the wheat seed sowing (WS); the second code is the application to the plots at the maize seed sowing (MS) and the third is the $\mathrm{N}$ application to maize plants in side dressing $(\mathrm{SD})$. The side dressing fertilization was applied at the $\mathrm{V}_{8}$ stage. In all treatments, wheat received 08$30-20$ doses of $\mathrm{N} 300 \mathrm{~kg} \mathrm{ha}^{-1}$ at seed sowing. Thus, the total $\mathrm{N}$ that wheat received at seed sowing was $120 \mathrm{~kg} \mathrm{ha}^{-1}$ added with $24 \mathrm{~kg} \mathrm{ha}^{-1}$ of formula, totalizing $144 \mathrm{~kg} \mathrm{ha}^{-1}$ of $\mathrm{N}$.

The need of $\mathrm{N}$ fertilizer in side dressing in the monitored treatment (T4) was calculated by means of chlorophyll meter readings (SPAD) and Nitrogen Supply Index (NSI), which was determined by the quotient of the leaf chlorophyll index (ICF) obtained from the parceled plot (T4) and the control one(T1). The whole nitrogen fertilization (120 kg N ha-1) is done during sowing, as follows:

$\mathrm{NSI}=\mathrm{ICF} \mathrm{sp} / \mathrm{ICF} \mathrm{cp}$

ICF $\mathrm{sp}=$ average of readings from the device in the studied plot; ICF $\mathrm{cp}=$ average of readings from the device in the control plot.
Newly-mature leaves from the fourth node up to the top were evaluated (SAINZ RozAS and ECHEVERRIA, 1998). The side dressing fertilization was necessary when NSI was smaller than 0.95 (Peterson et al., 1993).

The nutritional status was evaluated in the shoots of 10 plants (stem, leaves, straws and corncobs) and grains at the harvesting time to determine dry mass and nutrient content. Leaves of 10 plants were collected at the flowering stage. The plant chemical analyses followed the methods by Malavolta et al. (1997) and the N and S concentration was related with nutrients accumulated by maize.

The $\mathrm{N}$ and $\mathrm{S}$ utilization efficiency by maize shoots and grains was determined by the relation between the dry mass production and nutrients accumulated in the shoots or grains.

\section{RESULTS AND DISCUSSION}

\section{Maize productivity and grain production components}

Using variance analysis, the differences within 2 years were found (Table 2). In the first year, the complete doses of $\mathrm{N}\left(120 \mathrm{~kg} \mathrm{ha}^{-1}\right)$ and sulfur (144 $\left.\mathrm{kg} \mathrm{ha}^{-1}\right)$

Table 2. Grain productivity, ear length, number of ears per hectare and ear mass (grains + corncob) of maize after ammonium sulphate fertilization at seed sowing (MS), in side dressing (SD) and wheat seed sowing under no tillage system

\begin{tabular}{|c|c|c|c|c|c|c|c|c|}
\hline \multicolumn{9}{|c|}{ Growing season $2003 / 2004$} \\
\hline \multicolumn{4}{|c|}{ Fertilization (kg ha $\left.{ }^{-1}\right)$} & \multicolumn{5}{|c|}{ Components of grain production } \\
\hline \multicolumn{2}{|c|}{$\mathbf{N}$} & \multicolumn{2}{|c|}{$\mathbf{S}$} & \multicolumn{2}{|c|}{ Productivity } & \multirow{2}{*}{$\begin{array}{c}\text { Ear lengths } \\
(\mathrm{cm})\end{array}$} & \multirow{2}{*}{$\begin{array}{c}\text { Number of ears } \\
\text { (units ha-1) }\end{array}$} & \multirow{2}{*}{$\begin{array}{c}\text { Ear mass } \\
\text { (g) }\end{array}$} \\
\hline MS & SD & MS & SD & (ton ha-1) & (\%) & & & \\
\hline 120 & 0 & 144 & 0 & $8.03 \mathrm{a}$ & 154.0 & $16.90 \mathrm{a}$ & $86979.0 \mathrm{a}$ & $142.10 \mathrm{a}$ \\
\hline 0 & 120 & 0 & 144 & $8.18 \mathrm{a}$ & 157.0 & $17.20 \mathrm{a}$ & $76041.8 b$ & $134.70 \mathrm{a}$ \\
\hline 40 & 80 & 48 & 96 & $7.54 \mathrm{~b}$ & 144.5 & $16.40 \mathrm{a}$ & $77708.5 b$ & $125.70 \mathrm{a}$ \\
\hline 30 & $90^{(1)}$ & 36 & $108^{(1)}$ & $7.49 b$ & 143.7 & $16.50 \mathrm{a}$ & $78541.5 b$ & $130.40 \mathrm{a}$ \\
\hline $0^{(3)}$ & 0 & 0 & 0 & $7.24 \mathrm{~b}$ & 138.8 & $16.40 \mathrm{a}$ & $69375.0 \mathrm{c}$ & $127.70 \mathrm{a}$ \\
\hline 0 & 0 & 0 & 0 & $5.21 \mathrm{c}$ & 100.0 & $15.00 \mathrm{~b}$ & $59270.8 d$ & $102.20 \mathrm{~b}$ \\
\hline F test & & & & $34.420^{* *}$ & - & $6.246^{* *}$ & $30.877^{* *}$ & $14.542^{* *}$ \\
\hline Means & & & & 7.28 & - & 16.40 & 74652.8 & 131.50 \\
\hline CV(\%) & & & & 5.02 & - & 3.76 & 4.54 & 5.58 \\
\hline \multicolumn{9}{|c|}{ Growing season $2004 / 2005$} \\
\hline \multicolumn{4}{|c|}{ Fertilization (kg ha $\left.{ }^{-1}\right)$} & \multicolumn{5}{|c|}{ Components of grain production } \\
\hline \multicolumn{2}{|c|}{$\mathbf{N}$} & \multicolumn{2}{|c|}{$\mathbf{S}$} & \multicolumn{2}{|c|}{ Productivity } & lengths & Number of ears & Ear mass \\
\hline MS & SD & MS & SD & $($ ton ha-1) & (\%) & $(\mathrm{cm})$ & (units ha-1) & (g) \\
\hline 120 & 0 & 144 & 0 & $4.42 \mathrm{a}$ & 164.2 & 16.30 & $46875.0 \mathrm{a}$ & $114.20 \mathrm{a}$ \\
\hline 0 & 120 & 0 & 144 & $4.32 \mathrm{a}$ & 160.6 & 16.40 & $50000.0 \mathrm{a}$ & $118.70 \mathrm{a}$ \\
\hline 40 & 80 & 48 & 96 & $4.34 \mathrm{a}$ & 161.4 & 17.10 & $53125.0 \mathrm{a}$ & $120.90 \mathrm{a}$ \\
\hline 30 & $0^{(2)}$ & 36 & $0^{(2)}$ & $3.81 \mathrm{a}$ & 141.3 & 15.10 & $53125.0 \mathrm{a}$ & $101.10 \mathrm{~b}$ \\
\hline $0^{(3)}$ & 0 & 0 & 0 & $3.89 \mathrm{a}$ & 144.3 & 15.30 & $56250.0 \mathrm{a}$ & $107.10 \mathrm{~b}$ \\
\hline 0 & 0 & 0 & 0 & $2.69 \mathrm{~b}$ & 100.0 & 15.40 & $37500.0 \mathrm{~b}$ & $100.40 \mathrm{~b}$ \\
\hline $\mathrm{F}$ test & & & & $5.662^{*}$ & - & $1.749^{\text {ns }}$ & $4.326^{*}$ & $2.553^{*}$ \\
\hline Means & & & & 3.91 & - & 15.93 & 49479.2 & 110.38 \\
\hline CV (\%) & & & & 13.97 & - & 7.22 & 12.98 & 10.03 \\
\hline
\end{tabular}

Means with different small letters in the columns are statistically different at $\left({ }^{* *}\right) 1 \%$ and $\left(^{*}\right) 5 \%$ of probability by Scott-Knott's test.

${ }^{(1)} \mathrm{N}$ and S fertilization in maize side dressing; $\left({ }^{2}\right)$ Fertilization without $\mathrm{N}$ and S in maize side dressing according to the SPAD chlorophyll meter responses, Minolta. $\left({ }^{3}\right) \mathrm{N}(120 \mathrm{~kg}$ ha-1) and $S$ (144 kg ha-1) fertilization at wheat seed sowing.

MS: fertilization at maize seed sowing. SD: side dressing fertilization at the V8 stage. 
applied at seed sowing and at side dressing improved grain yield, length and mass of maize ears (grains + corncob) and the number of ears per hectare when the treatments were higher than the control and other treatments with ammonium sulphate. The productivity was $54 \%$ higher than the control when the fertilizer was completely applied at maize sowing, and 57\% when the complete dose of $\mathrm{N}$ and $\mathrm{S}$ was used in side dressed to maize plants in agreement with Von Pinho et al. (2008) who compared nitrogen sources $(120 \mathrm{~kg}$ $\mathrm{ha}^{-1}$ ), including ammonium sulphate, to management forms at seed sowing and/or side-dressing, and found high maize yield in treatments that received higher level of $\mathrm{N}$ in side-dressing (90 and $120 \mathrm{~kg} \mathrm{~N} \mathrm{ha}^{-1}$ ). The results can be explained by the increase of $\mathrm{N}$ and $\mathrm{S}$ utilization efficiency by plants in that year, when there was adequate rainfall distribution (Figure 1). However, in Brazil, the highest productivity of completely fertilized maize in side dressing can be related to soil texture as well as to soil organic matter, which was the initial nutrient source. These results were similar to the reports by Ceretta et al. (2002) and Silva et al. (2005) who also evaluated $\mathrm{N}$ management in maize crops. Sangakkara et al. (2008); Sangakkara and Stamp (2009) reported the beneficial impact of organic matter with low carbon C:N ratios in $\mathrm{N}$ nutrition enhancement and seed yields of maize, the most popular upland cereal in the Asian tropics.

Lara Cabezas et al. (2008) reported increases in maize productivity when $\mathrm{N}$ and $\mathrm{S}$, as ammonium sulphate, were applied to plants in the side dressing, because $\mathrm{N}$ volatilization reduction improves maize productivity. There were also increases in $S$ contents in the soil.

NSI determined by the chlorophyll meter reading, confirmed $\mathrm{N}$ requirements in side dressing application $(90$ $\mathrm{kg} \mathrm{N} \mathrm{ha}^{-1}$ ) and, likewise, maize productivity was similar to one with conventional applications at the maize seed sowing and side dressing (Table 2). According to Bullock and Anderson (1998), the reading corresponding to

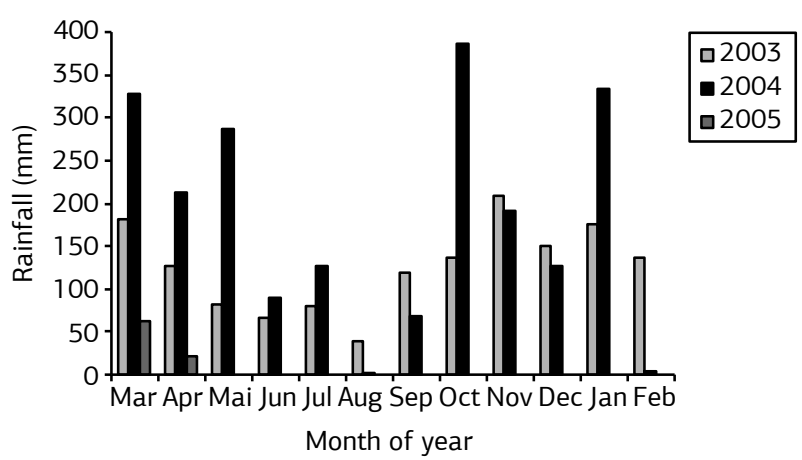

Figure 1. Rainfall during the experimental period on the COAMO Research Farm, Campo Mourão, PR (2003 - 2005). chlorophyll content is an accurate indicator of nitrogen level in maize development stages.

The maize yield was similar when the fertilization was applied at wheat sowing or when it was parceled (Table 2), which may be explained by the availability of both nutrients during the maize development. These results agree with Rodrigues et al. (2000) who reported that $70 \%$ of $\mathrm{N}$ accumulated in wheat plants was translocated from the vegetative plant parts to the grains and that $30 \%$ was maintained in the wheat shoots and then released into the soil during decomposition.

Furthermore, Herrera and LiedGens (2009) and Sholly et al. (2010) studied the importance of $\mathrm{N}$ to wheat crops. According to SHolly et al. (2010), N fertilizer tend to increase wheat growth and total vegetative tissue of $\mathrm{N}$ mass by $23 \%$ when compared to control.

In the first year, maize yield after complete $\mathrm{N}$ fertilization at the seed sowing was similar to the results by SANTOS et al. (2007) who reported 7.043 and $6.865 \mathrm{~kg} \mathrm{ha}^{-1}$ when $\mathrm{N}$ was totally applied at the seed sowing. However, maize yield decreased when the fertilization was parceled, differently from the high productivity levels reported by DUETE et al. (2008; 2009) who applied $135 \mathrm{~kg} \mathrm{ha}^{-1} \mathrm{~N}$ on a Red Latosol (Hapludox) at the 20, 40 and $60^{\text {th }}$ day during the growth period.

In second year, the productivities from the treatments with fertilizer management were higher than the control, but they were similar among themselves (Table 2). These responses can be attributed to nutrient leaching for $\mathrm{N}$ and $S$ and resulted into lower absorption and efficiency of these nutrients. In October, there was irregular rainfall distribution (Figure 1) and it can be related to nutrient movement in the profile. Therefore, the productivity was lower in that year. These data were corroborated by reports of Escosteghy et al. (1997) and DA Ros et al. (2003), who did not find any difference between application times. Arf et al. (2007) reported higher productivity when $\mathrm{N}$ fertilizer was completely applied at the seed sowing or then parceled. According to these authors, in the first and second year, the average of $\mathrm{N}$ fertilized treatments was $7.523 \mathrm{~kg} \mathrm{ha}^{-1}$ and $6.698 \mathrm{~kg} \mathrm{ha}^{-1}$, respectively. According to these authors, $\mathrm{N}$ had influence on the grain yield, which increased $29.4 \%$ and $47.4 \%$ in two years, respectively, when compared to the control, but without significant differences for application time.

High levels of production were obtained by Gomes et al. (2007), who divided $\mathrm{N}$ fertilization at maize seed sowing and side dressing. According to them, the average grain weight of $182 \mathrm{~g}$ per ear was obtained when $\mathrm{N}$ fertilization was applied only in side dressing, $30^{\text {th }}$ days after shoot emergence. However, the average grain weight of $172 \mathrm{~g}$ per ear was obtained when $\mathrm{N}$ fertilization was parceled at maize seed sowing and maize side dressing, at the $30^{\text {th }}$ day after emergence. Otherwise, the average grain weight of $175 \mathrm{~g}$ per ear occurred when the fertilizer was divided at 
maize seed sowing and maize side dressing at the 30 and $45^{\text {th }}$ after emergence. According to Gomes et al. (2007), maize productivity was 6.684 and $7.012 \mathrm{~kg} \mathrm{ha}^{-1}$ for $\mathrm{N}$ at 100 and $150 \mathrm{~kg} \mathrm{ha}^{-1}$. According to the authors, the second dose resulted in increase of grain productivity, $\mathrm{N}$ contents in leaves, grain weight and plant height.

In the second year, in treatment whose fertilization in side dressing was monitored by chlorophyll meter (treatment 4) and evaluated by the minimum Nitrogen Sufficiency Index (NSI) of 0.95, the crops was not fertilized in side dressing. The fertilization was only done at sowing with $30 \mathrm{~kg} \mathrm{ha}^{-1} \mathrm{~N}$ and $36 \mathrm{~kg} \mathrm{ha}^{-1} \mathrm{~S}$ (Table 2). In this treatment, the crop produced about $87 \%$ of the treatment fertilized with $120 \mathrm{~kg} \mathrm{~N} \mathrm{ha}^{-1} \mathrm{~N}$ and $144 \mathrm{~kg} \mathrm{ha}^{-1} \mathrm{~S}$ applied into the soil at the maize seed sowing or maize side dressing (Table 2). $\mathrm{N}$ and $\mathrm{S}$ levels may have been sufficient for plant growth because of the soil organic matter (Escosteghy et al., 1997).

The minimum NSI of 0.95 was not efficient to evaluate the foliar $\mathrm{N}$ content and predict side dressing requirements because there were yield losses when compared to other treatments (Table 2). Therefore, a more rigorous index could accurately predict $\mathrm{N}$ demand for side dressing application. In maize crops, for example, the relative chlorophyll or the leaf green color monitoring can help $\mathrm{N}$ availability evaluation for corn during the studied season that aimed to assess the use of the intensity of leaf green color (IGI), measured by a chlorophyll meter, as an indicator of nitrogen fertilizing management in side dress of corn crop, after $B$. decumbens Stapf pasture. (Godor et al. 2007).

Usually, the relationship between leaf $\mathrm{N}$ content and chlorophyll content is big, since an amount, between 50 to $70 \%$ of total $\mathrm{N}$, is part of enzymes associated to the chloroplasts (Blackmer and Schepers, 1995; Costa et al., 2001; ZeBarth et al., 2002).

\section{Nitrogen and sulphur accumulation in maize leaves and grains}

$\mathrm{N}$ and $\mathrm{S}$ accumulation in maize leaves and grains collected at harvesting stages were higher in all treatments with ammonium sulphate fertilization (Table 3). ZHANG et al. (1994) reported the favorable effect of nitrogen fertilizer in the synthesis and storage of cereal chemical compound

Table 3. Means of $\mathrm{N}$ and $\mathrm{S}$ accumulation in shoots (leaves, corncobs, straws and stems) and grains at the harvesting of maize and efficiency of nutrient utilization

\begin{tabular}{|c|c|c|c|c|c|c|c|c|c|c|c|}
\hline \multicolumn{12}{|c|}{ Growing season $2003 / 2004$} \\
\hline \multicolumn{4}{|c|}{ Fertilization $\left(\mathrm{kg} \mathrm{ha}^{-1}\right)$} & \multicolumn{4}{|c|}{ At harvesting $\left(\mathrm{kg} \mathrm{ha}^{-1}\right)$} & \multicolumn{4}{|c|}{$\begin{array}{l}\text { Efficiency of utilization } \\
\text { (kg material } \mathbf{~ k g}^{-1} \text { nutrient) }\end{array}$} \\
\hline \multicolumn{2}{|c|}{$\mathbf{N}$} & \multicolumn{2}{|c|}{$\mathbf{S}$} & $\mathbf{N}$ & S & $\mathbf{N}$ & S & $\mathbf{N}$ & S & $\mathbf{N}$ & S \\
\hline MS & SD & MS & SD & \multicolumn{2}{|c|}{ shoot } & \multicolumn{2}{|c|}{ grains } & \multicolumn{2}{|c|}{ shoot } & \multicolumn{2}{|c|}{ grains } \\
\hline 120 & 0 & 144 & 0 & $78.5 \mathrm{a}$ & $28.8 \mathrm{a}$ & $112.5 \mathrm{a}$ & $12.5 \mathrm{~b}$ & 191.8 & $515.0 \mathrm{a}$ & $69.0 \mathrm{a}$ & $542.5 \mathrm{a}$ \\
\hline 0 & 120 & 0 & 144 & $74.0 \mathrm{a}$ & $24.5 \mathrm{a}$ & $120.8 \mathrm{a}$ & $15.0 \mathrm{a}$ & 204.3 & $681.0 \mathrm{a}$ & $68.0 \mathrm{a}$ & $538.0 \mathrm{a}$ \\
\hline 40 & 80 & 48 & 96 & $58.5 b$ & $23.8 \mathrm{a}$ & $105.5 b$ & $11.5 b$ & 212.5 & $621.5 \mathrm{a}$ & $71.5 \mathrm{a}$ & $624.3 b$ \\
\hline 30 & $90^{(1)}$ & 36 & 108 & $75.3 \mathrm{a}$ & $20.5 b$ & $103.3 b$ & $13.0 \mathrm{~b}$ & 237.5 & $822.0 \mathrm{~b}$ & $72.5 \mathrm{a}$ & $580.5 b$ \\
\hline $0^{(3)}$ & 0 & 0 & 0 & $60.0 \mathrm{~b}$ & $18.3 \mathrm{~b}$ & $96.0 \mathrm{~b}$ & $13.5 b$ & 225.0 & $730.5 b$ & $75.5 \mathrm{a}$ & $547.8 \mathrm{~b}$ \\
\hline 0 & 0 & 0 & 0 & $44.7 \mathrm{~b}$ & $13.0 \mathrm{c}$ & $61.3 c$ & $9.0 \mathrm{c}$ & 237.5 & $838.0 \mathrm{~b}$ & $85.8 b$ & $700.0 \mathrm{c}$ \\
\hline Mean & & & & 65.2 & 17.9 & 99.9 & 12.50 & 218.1 & 701.3 & 73.8 & 583.8 \\
\hline$F$ test $(F$ & & & & $4.96^{* *}$ & $8.24^{* *}$ & $34.04^{* *}$ & $19.22^{* *}$ & ns & $3.98^{* *}$ & $7.58^{* *}$ & $17.40^{* *}$ \\
\hline CV (\%) & & & & 17.7 & 20.9 & 7.2 & 7.6 & 12.9 & 17.6 & 6.3 & 5.2 \\
\hline \multicolumn{12}{|c|}{ Growing season $2004 / 2005$} \\
\hline \multicolumn{4}{|c|}{ Fertilization $\left(\mathrm{kg} \mathrm{ha}^{-1}\right)$} & \multicolumn{4}{|c|}{ At harvesting ( $\mathbf{k g ~ h a}^{-1}$ ) } & \multicolumn{4}{|c|}{$\begin{array}{l}\text { Efficiency of utilization } \\
\text { (kg material } \mathbf{~ k g}^{-1} \text { nutrient) }\end{array}$} \\
\hline \multicolumn{2}{|c|}{$\mathbf{N}$} & \multicolumn{2}{|c|}{$\mathbf{S}$} & N & S & $\mathbf{N}$ & S & $\mathbf{N}$ & S & $\mathbf{N}$ & 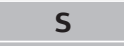 \\
\hline MS & SD & MS & SD & \multicolumn{2}{|c|}{ shoot } & \multicolumn{2}{|c|}{ grains } & \multicolumn{2}{|c|}{ shoot } & \multicolumn{2}{|c|}{ grains } \\
\hline 120 & 0 & 144 & 0 & $196.3 \mathrm{a}$ & $7.0 \mathrm{a}$ & $72.8 \mathrm{a}$ & $3.0 \mathrm{a}$ & $74.3 \mathrm{a}$ & $1966.3 \mathrm{a}$ & $61.0 \mathrm{a}$ & $1351.5 \mathrm{a}$ \\
\hline 0 & 120 & 0 & 144 & $168.8 \mathrm{a}$ & $5.5 \mathrm{~b}$ & $68.3 \mathrm{a}$ & $3.3 \mathrm{a}$ & $81.0 \mathrm{a}$ & $1912.3 \mathrm{a}$ & $64.0 \mathrm{a}$ & $1334.8 \mathrm{a}$ \\
\hline 40 & 80 & 48 & 96 & $95.3 \mathrm{~b}$ & $4.5 \mathrm{~b}$ & $62.3 \mathrm{a}$ & $3.3 \mathrm{a}$ & $121.5 \mathrm{~b}$ & $2589.8 \mathrm{a}$ & $72.0 \mathrm{a}$ & $1419.0 \mathrm{a}$ \\
\hline 30 & $0^{(2)}$ & 36 & 0 & $97.3 \mathrm{~b}$ & $4.3 \mathrm{~b}$ & $47.0 \mathrm{~b}$ & $2.8 \mathrm{a}$ & $163.3 \mathrm{c}$ & $3646.0 \mathrm{~b}$ & $82.8 \mathrm{a}$ & $1379.3 \mathrm{a}$ \\
\hline $0^{(3)}$ & 0 & 0 & 0 & $76.5 \mathrm{~b}$ & $1.8 \mathrm{c}$ & $55.5 \mathrm{a}$ & $3.0 \mathrm{a}$ & $163.3 \mathrm{c}$ & $5606.0 \mathrm{c}$ & $70.5 \mathrm{~b}$ & 1500.0 b \\
\hline 0 & 0 & 0 & 0 & $41.0 \mathrm{c}$ & $1.3 c$ & $27.8 \mathrm{c}$ & $1.5 \mathrm{~b}$ & $212.5 \mathrm{~d}$ & $6913.5 \mathrm{~d}$ & $97.0 \mathrm{~b}$ & $1814.0 \mathrm{~b}$ \\
\hline Mean & & & & 112.5 & 3.9 & 55.6 & 2.8 & 136.0 & 3711.3 & 74.5 & 1433.1 \\
\hline$F$ test $(F$ & & & & $33.89^{* *}$ & $20.00^{* *}$ & $13.62^{* *}$ & $8.36^{* *}$ & $23.65^{* *}$ & $27.24^{* *}$ & $6.65^{* *}$ & $9.61^{* *}$ \\
\hline CV (\%) & & & & 17.9 & 25.3 & 16.0 & 16.3 & 16.2 & 21.0 & 13.8 & 8.6 \\
\hline
\end{tabular}

Means with different small letters in the columns are statistically different at $\left(^{* *}\right) 1 \%$ and $\left(^{*}\right) 5 \%$ of probability or no significant (ns) by Scott-Knott's test.

(1) Fertilization according to the SPAD chlorophyll meter responses, Minolta with $\mathrm{N}$ at maize side dressing; $\left(^{2}\right)$ Without $\mathrm{N}$ at maize side dressing. ${ }^{(3)}$ Fertilization at the wheat seed sowing (WS) with $\mathrm{N}\left(120 \mathrm{~kg} \mathrm{ha}^{-1}\right)$ and $\mathrm{S}\left(144 \mathrm{~kg} \mathrm{ha}^{-1}\right)$.

MS: fertilization at maize seed sowing. SD: side dressing fertilization at the V8 stage. 
grains as protein, lipids and carbohydrate concentrations during the course of maize.

In the first year, there was higher $\mathrm{N}$ than $\mathrm{S}$ accumulation in the grain, as well as $\mathrm{N}$ utilization efficiency for grains. The means of both nutrients were higher than reported by Silva et al. (2009b), who applied ammonium sulphate to maize under no tillage in similar treatments after oats crops in Red Latosol dystrophic (Hapludox) under no tillage system.

$\mathrm{N}$ and $\mathrm{S}$ accumulated in maize vegetative parts and grain was different from the utilization efficiency by the crop (Table 3). Therefore, the accumulation was higher when fertilization was completely applied at maize sowing or side dressing. In both treatments, consequently, the nutrients had less utilization efficiency. However, there was less $\mathrm{N}$ and $\mathrm{S}$ accumulation in shoots and grains for parceled fertilization, regardless the chlorophyll monitoring. Reduced percolation in the soil profile and the best use of the $\mathrm{N}$ fertilization could explain it. Duete et al. (2009) reported that $\mathrm{N}$ fertilization at the $\mathrm{V}_{8}$ stage caused high nutrient accumulation in grains. The $\mathrm{N}$ content estimates were $121.2 \mathrm{~kg} \mathrm{ha}^{-1}$ and $117.4 \mathrm{~kg} \mathrm{ha}^{-1}$ for nutrient sources as urea and ammonium nitrate.

In second year the $\mathrm{N}$ and $\mathrm{S}$ accumulated more in shoots in comparison at grain, as well as the utilization efficiency was higher for shoots, probably due to the lower productivity in that year (Table 3 ).

The control presented high $\mathrm{N}$ and $\mathrm{S}$ utilization efficiency (Table 3) which was related to a smaller quantity of these nutrients in the maize plant and grains, compared with the fertilizer doses, as previously reported (MunIz et al., 1985; Heringer and Moojen, 2002; Magalhấes et al., 2007). The quadratic response between the $\mathrm{N}$ utilization efficiency and dry matter production of Signal grass was reported by MAGAlHÂES et al. (2007). The grass production was reduced when the $\mathrm{N}$ doses were increased. The maximum of $18.84 \mathrm{~kg}$ of dry mass $\mathrm{kg}^{-1}$ of $\mathrm{N}$ was achieved for $245.3 \mathrm{~kg} \mathrm{ha}^{-1} \mathrm{~N}$. Negative and linear responses were reported by Heringer and Moojen (2002) who studied $\mathrm{N}$ utilization efficiency in pearl millet for doses up to $600 \mathrm{~kg} \mathrm{ha}^{-1}$.

\section{Nitrogen and sulphur in leaves and grain and correlation with maize yield}

In both years, the correlation coefficients between maize productivity and $\mathrm{N}$ and $\mathrm{S}$ accumulated in grains or accumulated in shoots (leaves, corncobs, straws and stems) was high (Table 4) because of the numerous functions of nutrients in the plants (Marschner, 1995; Barber and Pilbeam, 2006).

The $\mathrm{N}$ accumulation in plants and grains were in agreement with the reports by Zotarelli et al. (2003) who evaluated the concentration in the maize grains and straw after lupine and oats crops under no-tillage system on clay soil in Paraná State, Brazil.

The average of $\mathrm{N}$ accumulation in leaves collected at flowering stage and in shoots and grains collected at harvesting were $69.3,69.7$ and $78.8 \mathrm{~kg} \mathrm{ha}^{-1}$, respectively. The averages of $S$ accumulation were $5.9,13.0$ and $7.9 \mathrm{~kg} \mathrm{ha}^{-1}$, respectively. Under different fertilization managements, DueTe et al. (2008) found $\mathrm{N}$ accumulation in the maize shoots after the harvesting of 33.2 to $58.2 \mathrm{~kg} \mathrm{ha}^{-1}$ relative to levels of $180 \mathrm{~kg} \mathrm{ha}^{-1} \mathrm{~N}$. According to the authors, in the $\mathrm{V}_{8}$ stage, the application of $135 \mathrm{~kg} \mathrm{ha}^{-1} \mathrm{~N}$ increased productivity and nutrient efficiency. According to RHEINHEIMER et al. (2005), the $S$ export by the grains ranged from 11.5 to $17.5 \mathrm{~kg} \mathrm{ha}^{-1}$, when maize was cultivated after wheat in Red Argisol (Hapludalf).

\section{CONCLUSION}

Ammonium sulphate application improved maize yield, regardless of fertilizer management, that is, when it was done at seeding, side dressing or both management forms.

The Nitrogen Sufficiency Index (NSI) of 0.95 was not efficient to evaluate maize $\mathrm{N}$ requirements at side dressing and its non-application resulted in lower yield.

Higher maize yield increase $\mathrm{N}$ accumulated in grains although this nutrient was more efficient in the aerial part. Accumulated S, as well as the nutrient utilization efficiency, was higher in the aerial part when compared to $S$ in grains.

Table 4. Correlation coefficients between productivity and $\mathrm{N}$ and $\mathrm{S}$ concentration and accumulation, accumulation in maize during, during two growing seasons

\begin{tabular}{lcccccc} 
Variable & $\mathbf{N}^{(1)}$ & $\mathbf{S}^{(1)}$ & $\mathbf{N}^{(3)}$ & $\mathbf{S}^{(3)}$ & $\mathbf{N}^{(5)}$ & $\mathbf{S}^{(5)}$ \\
\hline Productivity & $0.8055^{* *}$ & $0.6799^{* *}$ & $0.5396^{*}$ & $0.7317^{* *}$ & $0.7033^{* *}$ & $0.1228^{\mathrm{ns}}$ \\
Productivity & $0.5562^{* *}$ & $0.5892^{* *}$ & $0.6051^{* *}$ & $0.6231^{* *}$ & $0.7284^{* *}$ & $0.6869^{*}$ \\
Variable & $\mathbf{N}^{(2)}$ & $\mathbf{S}^{(2)}$ & $\mathbf{N}^{(4)}$ & $\mathbf{S}^{(4)}$ & $\mathbf{N}^{(6)}$ & $\mathbf{S}^{(6)}$ \\
Productivity & $0.7083^{* *}$ & $0.4243^{*}$ & $0.6676^{* *}$ & $0.7601^{* *}$ & $0.9615^{* *}$ & $0.5351^{* *}$ \\
Productivity & $0.8172^{* *}$ & $0.6223^{* *}$ & $0.5667^{* *}$ & $0.6888^{* *}$ & $0.9017^{* *}$ & $0.8951^{* *}$
\end{tabular}

Significant and non significant (ns) at $5.0 \%\left({ }^{*}\right)$ and $1.0 \%\left({ }^{* *}\right)$, according to statistical test SAS.

$\left({ }^{1}\right)$ nutrients concentration at flowering stages during two growing seasons; $\left({ }^{2}\right)$ leaf accumulation at flowering stages during two growing seasons; $\left({ }^{3}\right)$ nutrient concentration in aerial parts (stems, leaves, straws and corncobs); ( $\left.{ }^{4}\right)$ accumulation in aerial parts; $\left({ }^{5}\right)$ nutrient concentration in grains at harvesting time; $\left({ }^{6}\right)$ accumulation in grains at harvesting time. 


\section{REFERENCES}

ARF, O.; FERNANDES, R.N.; BUZETTI, S.; RODRIGUES, R.A.F.; SÁ, M.E.; ANDRADE, J.A.C. Manejo do solo e época de aplicaçáo do nitrogênio no desenvolvimento e rendimento do milho. Acta Scientiarum Agronomy, v.29, p.211-217, 2007.

BARBER, A.V.; PILBEAM, D.J. Handbook of Plant Nutrition. Taylor and Francis Publications. Boca Raton, Florida, USA, 2006.

BLACKMER, T.M.; SCHEPERS, J.S. Techniques for monitoring crop nitrogen status in corn. Communication in Soil Science and Plant Analysis, v.25, p.1791-1800, 1995.

BÜLL, L.T. Nutrição mineral do milho. In: BÜLL, L.T.; CANTARELLA, H. A cultura do milho: fatores que influenciam no rendimento. Piracicaba: Associação Brasileira para Pesquisa da Potassa e do Fosfato. 1993. p.63-121.

BULLOCK, D.G.; ANDERSON, D.S. Evaluation of the Minolta SPAD 502 chlorophyll meter for nitrogen management in corn. Journal of Plant Nutrition, v.21, p.741-755. 1998.

CERETTA, C.A.; BASSO, C.J.; DIEKOW, J.; AITA, C.; PAVINATTO, P.S.; VIEIRA, F.C.B.; VENDRUSCLO, E.R.O. Nitrogen fertilizer split-application for corn in no-tillage succession to black oats. Scientia Agricola, v.59, p.549-554. 2002.

COSTA, C.; DWYER, L.M.; DUTILLEUL, P.; STEWART, D.W.; M.A., B.L.; SMITH, D.L. Inter-relationships of applied nitrogen, SPAD, and yield of leafy and non-leafy maize genotypes. Journal of Plant Nutrition, v.24, p.1173-1194, 2001.

DA ROS, C.O.; SALET, R.L.; PORN, R.L.; CORREAA, J.N.C. Disponibilidade de nitrogênio e produtividade de milho e trigo com diferentes métodos de adubaçáo nitrogenada no sistema plantio direto. Ciência Rural, v.33, p.799-804, 2003.

DUETE, R.R.C.; MURAOKA, T.; SILVA, E.C.; TRIVELIN, P.C.O.; AMBROSANO, E.J. Manejo da adubaçáo nitrogenada e utilização do nitrogênio $\left({ }^{15} \mathrm{~N}\right)$ pelo milho em Latossolo Vermelho. Revista Brasileira de Ciência do Solo, v.32, p.161-173, 2008.

DUETE, R.R.C.; MURAOKA, T.; SILVA, E.C.; AMBROSANO, E.J.; TRIVELIN, P.C.O. Acúmulo de $\left({ }^{15} \mathrm{~N}\right)$ pelos grãos de milho em função da fonte nitrogenada em Latossolo Vermelho. Bragantia, v.68, p.463-472, 2009.

EMBRAPA. Empresa Brasileira de Pesquisa Agropecuária. Manual de Métodos de Análise de Solo. 2.ed. Embrapa Solos. Rio de Janeiro. 1997. 212p.

EMBRAPA. Empresa Brasileira de Pesquisa Agropecuária. Sistema Brasileiro de Classificação de Solo. Rio de Janeiro, Centro Nacional de Pesquisa de Solos, 1999. 412p.

ESCOSTEGUY, P.A.V;; RIZZARDI, M.A.; ARGENTA, G. Épocas de aplicação de nitrogênio em cobertura na cultura do milho em duas épocas de semeadura. Revista Brasileira de Ciência do Solo, v.21, p.71-77, 1997.

FERREIRA, D.F. SISVAR - Sistema de análise estatística para dados balanceados. Lavras: UFLA/DEX, 2000. Programa de computador.
GODOY, L.J.G.; SOUTO, L. S.; FERNANDES, D.M.; VILLAS BOAS, R.L. Use of chlorophyll meter in nitrogen fertilizing management to corn after Brachiaria decumbens pasture. Ciência Rural, v.37, p. 38-44, 2007.

GOMES, R.F.; SILVA, A.G.; ASSIS, R.L.; PIRES, F.R. Efeito de doses e de época de aplicação de nitrogênio nos caracteres agronômicos da cultura do milho sob plantio direto. Revista Brasileira de Ciência do Solo, v.31, p.931-938, 2007.

HERINGER, I.; MOOJEN, E.L. Productive potential, structure changes and quality of pearl millet under different nitrogen levels. Revista Brasileira de Zootecnia, v.31, p.875-882, 2002. (suplemento).

HERRERA, J.M.; LIEDGENS, M. Leaching and utilization of nitrogen during a spring wheat catch crop succession. Journal of Environmental Quality, v.38, p.1410-1419, 2009.

LARA CABEZAS, W.A.R.; TRIVELIN, P.C.O.; KONDORFER, G.H.; PEREIRA, S. Balanço da adubação nitrogenada sólida e fluida de cobertura na cultura do milho, em sistema plantio direto no triângulo mineiro (MG). Revista Brasileira de Ciência do Solo, v.24, p.363-376, 2000.

LARA CABEZAS, W.A.R; COUTO, P.A. Imobilização de nitrogênio da uréia e do sulfato de amônio aplicado em présemeadura ou cobertura na cultura do milho no sistema plantio direto. Revista Brasileira de Ciência do Solo, v.31, p.739-752, 2007.

LARA CABEZAS, W.A.R.; RODRIGUES, C.R.; OLIVEIRA, S.M.; BORGES, E.N. Uso da uréia misturado ao sulfato de amônio ou gesso na cultura do milho. Revista Brasileira de Ciência do Solo, v.32, p.2343-2353, 2008.

MAGALHÂES, A.F.; PIRES, A.J.V.; CARVALHO, G.G.P.; SILVA, F.F.; SOUZA, R.S.; VELOSO, C.M. Influência do nitrogênio e fósforo no crescimento de capim braquiária. Revista Brasileira de Zootecnia, v.36, p.1240-1246, 2007.

MALAVOLTA, E.; VITTI, G.C.; OLIVEIRA, S.A. Avaliação do estado nutricional das plantas: princípios e aplicaçôes. Piracicaba: Potafós. 1997, 319p.

MARSCHNER, H. Mineral nutrition of higher plants. 2.ed. London: Academic Press, 1995. 889p.

MINOLTA CAMERA. Manual for chlorophyll meter SPAD 502. Osaka: Minolta. Radiometric Instruments Divisions, 1989. 22p.

MUNIZ, A.S.; NOVAIS, R.F.; BARROS, N.F.; NEVES, J.C.L. Nível crítico de fósforo na parte aérea da soja como variável do fator capacidade de fósforo no solo. Revista Brasileira de Ciência do Solo, v.9, p.237-243, 1985.

PETERSON, T.A.; BLACKMER, T.M.; SCHEPERS, J.S. Using a chlorophyll meter to improve $\mathrm{N}$ management. Lincoln: University of Nebraska. Cooperative Extension. Institute of Agricultural a Natural Resources, 1993. 5p.

RHEINHEIMER, D.S.; ALVAREZ, J.W.R.; OSORIO FILHO, B.D.; SILVA, L.S.; BORTOLUZZI, E.C. Resposta de culturas 
à aplicação de enxofre e a teores de sulfato num solo de textura arenosa sob plantio direto. Ciência Rural, v.35, p.562-569, 2005.

RODRIGUES, O.; DIDONET, A.D.; GOUVEIA, J.A.; SOARES, R.C. Translocação do nitrogênio em trigo inoculado com Azospirillum e adubado com nitrogênio. Pesquisa Agropecuária Brasileira, v.25, p.1473-1481, 2000.

SAINZ-ROZAS, H.S.; ECHEVERRIA, H.E. Relación entre las lecturas del medidor de clorofila (Minolta SPAD 502) en distintos estadios del ciclo del cultivo de maíz y el rendimiento en grano. Revista de la Facultad de Agronomia, v.103, p.37-44, 1998.

SANGAKKARA, U.R.; ATTANAYAKE, K.P.; STAMP, P. Impact of locally derived organic materials and method of addition on maize yields and nitrogen use efficiencies in major and minor seasons of tropical South Asia. Communication in Soil Science and Plant Analysis, v.39, p.2584-2596, 2008.

SANGAKKARA, U.R.; STAMP, P. Productivity and nitrogen use of maize as affected by in situ and ex situ green manuring in major and minor seasons of tropical Asia. Acta Agronomica Hungarica, v.57, p.285-296, 2009.

SANGOI, L.; ERNANI, P.R.; SILVA, P.R.F. Resposta do milho à épocas de adubaçáo nitrogenada em plantio direto e alto conteúdo de material orgânica. Revista Brasileira de Ciência do Solo, v.31, p.507-517, 2007.

SANTOS, M..M.; GALVÃO, J.C.C.; MIRANDA, G.V.; FERREIRA, L.R.; MELO, A.V.; FONTANETTI, A. Espaçamento entre fileiras e adubação nitrogenada no milho. Acta Scientiarum Agronomy, v.29, p.527-533, 2007.

SEAB. Secretaria Estadual de Abastecimento - Curitiba. PR. Grain culture. cotton and other cultures of Paraná State: evaluation of area in a harvest time and production obtained in 2008. Disponível em: <http://www.pr.gov.br/seab. Acesso em: 27/1/2009.

SHOLLY, D.M.; RICHERT, B.T.; SUTTON, A.L.; JOERN, B.C. Effect of nitrogen and phosphorus from swine manure on winter wheat growth and nutrient utilization. Communication in Soil Science and Plant Analysis, v.41, p.1797-1815, 2010.

SILVA, E.C.; FERREIRA, S.M.; SILVA, G.P.; ASSIS, R.L.; GUIMARÃES, G.L. Época e métodos de aplicação de nitrogênio em milho em solos de cerrado. Revista Brasileira de Ciência do Solo, v.29, p.725-733, 2005.

SILVA, E.C.; MURAOKA, T.; BUZETTI, S.; VELOSO, M.E.C; TRIVELIN, P.C.O. Absorção do nitrogênio nativo do solo pelo milho sob plantio direto em sucessão a plantas de cobertura. Revista Brasileira de Ciência do Solo, v.30, p.723-732, 2006.

SILVA, E.C.; MURAOKA, T.; BUZETTI, S.; SPINAL, F.S.C.; TRIVELIN, P.C.O. Utilização do nitrogênio da palha de milho e de adubos verdes pela cultura do milho. Revista Brasileira de Ciência do Solo, v.32, p.2853-2861, 2008.

SILVA, E.C.; MURAOKA, T.; VILLANUEVA, F.C.A.; SPINAL, F.S.C. Aproveitamento de nitrogênio pelo milho em razão da adubaçáo verde, nitrogenada e fosfatada. Pesquisa Agropecuária Brasileira, v.44, p.118-127, 2009a.

SILVA, M.A.G.; PORTO, S.M.A.; MANNIGEL, A.R.; MUNIZ, A.S.; MATA, J.D.V.; NUMOTO, A.Y. Manejo da adubação nitrogenada em relação ao crescimento da aveia preta e produtividade do milho em plantio direto. Acta Scientiarum Agronomy, v.31, p.275-281, 2009b.

VON PINHO, R.G.; GROSS, M.R.; STEOLA, A.G.; MENDES, M.C. Adubaçáo nitrogenada densidade e espaçamento de híbridos de milho em sistema plantio direto na região sudeste do Tocantins. Bragantia, v.67, p.733-739, 2008.

ZHANG, F. MACHENZIE, A.F.; SMITH, D.L. Nitrogen fertilizer and protein, lipid, and non-structural carbohydrate concentration during the course of maize kernel filling. Journal of Agronomy and Crop Science, v.172, p.171-181, 1994.

ZEBARTH, B.J.; YOUNIE, M.; PAUL, J.W.; BITTMAN, S. Evaluation of leaf chlorophyll index for making fertilizer nitrogen recommendations for silage corn in a high fertility environment. Communications in Soil Science and Plant Analysis, v.33, p.665684, 2002.

ZOTARELLI, L.; CARDOSO, E.G.; PICCININ, J.L.; URQUIAGA, S.; BODDEY, R.M.; TORRES, E.; ALVES, B.J.R. Calibração do clorofilômetro Minolta SPAD-502 para avaliar o estado nutricional de nitrogênio em milho. Revista Brasileira de Ciência do Solo, v.38, p.1117-1122, 2003. 